\title{
A PETRIFIED DICOTYLEDONOUS LEAF MOHGAOPHYLLUM DECCANII FROM MOHGAONKALAN, M.P, INDIA
}

\author{
S. D. Puranik \\ Shri Shivaji Science College, Nagpur \\ sumedhadpuranik@gmail.com
}

Communicated : 11.02 .19

Revision : 10.03 .19

Accepted : 15.04.19

Published: 30.05 .19

\begin{abstract}
:
A petrified dicotyledonous leaf from the Deccan Intertrappean Cherts of Mohagaonkalan, Chindawara district, M.P., India.so far many dicotyledonous and monocotyledonous leaf impression have been studied by many workers. There is scanty record of petrified leaves from these beds. Leaf petrified, dicotyledonous, doriventral, hypostomatic, epidermis hairy, unilayered, mesophyll differentiated into palisade, spongy parenchyma, canals in mesophyll, arc shaped vascular bundle in midrib with distinct bundle sheath, vascular bundle conjoint, collateral, concentric, veinlet bundle, conjoint, collateral, concentric with bundle sheath. It is named as Mohgaophyllum deccanii gen.et sp.nov. generic name is given after the locality and the specific name is given the horizon.
\end{abstract}

Key words: - fossil leaf, sedimentary beds, dicotyledonous, dorsiventral etc.

\section{INTRODUCTION:}

This chapter deals with the detailed description of dicotyledonous leaf from the Deccan Intertrappean Cherts of Mohagaonkalan, Chindawara district, M.P., India.so far many dicotyledonous and monocotyledonous leaf impression have been studied by many workers. There is scanty record of petrified leaves from these beds. Sheikh and Kolhe (1978) reported petrified dicotyledonous leaf that is, Deccanophyllum intertrappea from Mohagaonkalan. Kolhe (1980) included two more leaf genera Dorsiventrophyllum and Morophyllum from the same beds. Karanjekar (1982) reported new leaf genus Cornaceophyllum intertrappea. Julianiophyllum sahnii Kapgate (1982) , Salicaceophyllum mohgaonsis Kapgate D.K \& Sheikh M.T. (2008), Deccanophyllites sheikhii (Kokate P.S, 2014), Acanthophyllum shiblii (Ramteke D.D \&Kapgate D.K., 2014). The leaf studied here is the further addition to the knowledge of leaves from this area.

\section{MATERIAL AND METHODS :-}

Some silicified cherts were collected from Mohgaonkalan. While observing the pieces of these cherts, the present leaf specimen was seen showing good preservation. After etching it with hydrofluoric acid, serial peel section were taken from transverse plane.

DESCRIPTION: The leaf is dorsiventral, swollen in the midrib portion showing main vascular bundle and lateral veins in the lamina. Stomatal gaps are seen on the lower side. Lamina is hairy and canals are also seen in the lamina (Plate I, Figs. 1 \& 2).

The leaf is dorsiventral, having swollen midrib on lower side (Plate I, Figs. 1,2\&4). It is $0.57 \mathrm{~mm}$ thick in the midrib and $0.20 \mathrm{~mm}$ thick in the laminar region. The lamina is board measures 12.12-12.30 $\mathrm{mm}$ in breadth, on right side $7.42-8 \mathrm{~mm}$ broad and on the left side 3.6-3.9 mm broad from the midrib. Lamina is more or less uniform in thickness expect at veins and veinless where it is slightly bulged ranging in thickness from $0.2-0.28 \mathrm{~mm}$.

The upper epidermis is single layered, covered with thick cuticle, the cells of which are squarish, 20$25 \mu$ in diameter (Plate I, Figs. 2,3,4\&5). Unicellular hairs are seen arising from the upper epidermis. These are poorly preserved. These are $21-23 \mu$ in length and $3-6 \mu$ in breadth.

This layered is followed by mesophyll tissue which is differentiated into single layered palisade and 2-3 layered spongy parenchyma. The palisade cells are compactly contents (Plate I, Figs. 2,3,\&4). These are $53.9-69.3 \mu$ in length and $23.1-30 \mu$ in breadth. The cells of spongy parenchyma are polygonal, loosely arranged measuring 23.1-40.5 $\mu$ in diameter (Plate I, Figs. 2\&3). Roundish canals are seen in mesophyll, measures $0.1 \mathrm{~mm}$ in diameter. These are bounded by a single layer of epithelial cells. These cell are thin walled. Brownish 
dark contents are seen in the canals (Plate I, Figs. 3).

Spongy parenchyma is followed by lower epidermis. It is poorly preserved and cells are same as upper epidermis but these are comparatively smaller measuring $18-22.4 \mu$ in diameter. (Plate I,Figs. 3).hairs are not prominent on this layer. Some gaps are observed on the lower epidermis (Plate I, Figs. 2). However typical stomatal structure is not clear. The midrib region is triangular in shape, showing centrally situated vascular strand (Plate I, Figs. $2 \& 4)$. The vascular bundle is arc shaped, conjoint, collateral and concentric. Xylem elements are 1012 facing the upper side (Plate I, Figs. 2\&4). Xylem vessels are $26-46 \mu$ in diameter. A prominent bundle sheath is seen enclosing the vasculature. The cells of this layer are sclerenchymatous and thick walled, $28-30 \mu$ in diameter (Plate I, Fig. 4).

The vascular strands of the lateral veins are seen in the lamina.it is conjoint, collateral and concentric. They show 6-7 xylem elements, $40-42 \mu$ in diameter surrounded by thin walled polygonal parenchymatous cells (Plate I, Fig.5). These cells are $30-35 \mu$ in diameter.

IDENTIFICATION AND DISCUSSION: From the above description, it is evident that the fossil leaf under consideration is dorsiventral and therefore belongs to dicotyledonous family. The important anatomical characters of this leaf are as follows:

1. Single layered hairy epidermis with cuticle.

2. Absence of hypodermis.

3. Mesophyll differentiated into single layered palisade and 2-3 layered spongy parenchyma.

4. Presence of canals in mesophyll.

5. Stomatal gaps restricted to lower epidermis.

6. Single median vascular bundle with bundle sheath.

This leaf is compared with earlier reported fossil leaves. When it is compared with Deccanophyllum intertrappea (kolhe and Sheikh, 1978). It is seen that present leaf differs in, not having palisade in two rows and air cavities in spongy parenchyma. Canals and hairy epidermis are also lacking.

Dorsiventrophyllum agashii (Kolhe, 1980) shows large parenchymatous epidermis cells with conical apex, vascular bundle without sheath and absence of canals. These characters are not seen in presence leaf.

Julianiophyllum sahni (Kapgate, 1982) differs from this leaf in having smooth epidermis and vessels of midrib are radially arranged.
Cornaceophyllum intertrappea (Karanjekar, 1982) differs from the present specimen in having idioblast cells, large parenchymatous pith, in vascular bundle, vessels are radially arranged, additional subsidiary bundles and absence of canals.

From the above characters it is seen that the present leaf is different from the other leaves reported from this horizon.

The affinities were further traced with modern genera. The specimen is comparable with Guttiferae, Hypericaceae, Julianiaceae, Celastraceaea and Cornaceae, families of Angiosperm.

The leaves of family Gulltiferae shows similarity in the presence of canals, stomata on lower side, arc shaped vascular bundle and hairy epidermis. But in Gulltiferae hypodermis is present and mesophyll is reticulate (Metcalfe and Chalk, 1950). The leaves Hypericaceae although identical, does not show bundle sheath which is definite character of the present specimen.

The leaves of family Julicaniaceae are comparable with this specimen but occurance of resin canals in phloem of vascular bundles of veins and enlarged idioblasts in the mesophyll, are the characters lacking in this leaves.

The family Celastraceae show following characters comparable with this leaves, like epidermis with cuticle, secretory canals in mesophyll, stomata on lower side, simple and single vascular strand. But sclerechyma in vascular bundles of veins and homogenous mesophyll are the two characters which separates it from this specimen.

The Cornaceae leaves are closely comparable with this leaves. When the comparisons are made on generic level, it shows epidermis with unicellular hairs and outer walls of epidermis thickened like Corokia, Curtisia and Griselinia. Mesophyll is differentiated into single layered palisade as in Cornus and Curtisia and 1-2 layered in Mastixia (Metcalfe and Chalk, 1950). According to Faure (1924), midrib shows single vascular strand as in Curtisia and Griselinia. Sclerenchymatous sheath is present as in Mastixia. The hypodermis is confirmed only in Griselinia. In other species it is not known (Metcalfe and Chalk, 1950). Canals observed in the cortex of Mastixia.

Thus the present fossil does not resemble extant and extinct genera. The different are assorted amongs various genera of cornaceae although it is somewhat close to Curtisia and Mastixia. It is named as Mohgaophyllum deccanii gen.et sp.nov. 
generic name is given after the locality and the specific name is given the horizon.

\section{DIAGONISIS:}

\section{Generic Diagnosis:-}

\section{Mohgaophyllum gen.nov.}

Leaf petrified, dicotyledonous, doriventral, hypostomatic, epidermis hairy, unilayered, messophyll differentiated into palisade, spongy parenchyma, canals in mesophyll, arc shaped vascular bundle in midrib with distinct bundle sheath, vascular bundle conjoint, collateral, concentric, veinlet bundle, conjoint, collateral, concentric with bundle sheath.

Specific diagonisis:-

M.deccanii sp. nov.

Leaf $12.12 \times 12.30 \mathrm{~mm}$ broad, midrib $0.57 \mathrm{~mm}$ thick, lamina $0.20 \mathrm{~mm}$ thick, epidermis single layer with thick cuticle 20-25 $\mu$ thick, unicellular hairs present, stomata on lower side, palisade cells thick walled, 53.9 - $69.3 \mu$ long, 23.1-30 $\mu$ broad, loose spongy parenchyma, cells $23.1-40.5 \mu$ in diameter, canals roundish, $0.1 \mathrm{~mm}$ in diameter with brownish content, stomatal gaps on lower epidermis, vascular bundle arc shaped, xylem elements 10-12, vessels 26-46 $\mu$ in diameter, veinlet bundles with 67 vessels, $30-35 \mu$ in diameter.

Holotype- deposited in Department of Botany, Institute of Science, Nagpur.

Locality- Mohagaonkalan, chhindwara district, M.P., India.

Locality- Mohagaonkalan, chhindwara district, M.P., India.

Horizon- Deccan Intertrappean series of India

Age- upper most cretaceous.

Mohgaophyllum deccanii gen. et sp. nov.

\section{REFERENCES:-}

Agashe, L. V. and Gupte R. B., (1968). Some significant features of the deccan trap. Seminar volume on "Cretaceous India". Memoir no. 2, Geol. Soc. India.

Explanation of plate I, Figs. 1-5

1. T.S. leaf showing midrib (m) and lamina (1) x 11 .

2. T.S. midrib showing upper epidermis (e), mesophyll $(\mathrm{m})$, vasculature (vb) and stomatal gap (s) on lower side $\mathrm{x} 45$.

3. T.S. laminar region showing upper and lower epidermis, canal (c) and mesophyll x 150.

4. T.S. midrib showing arc shaped vascular bundle (vb) with bundle sheath (bs) x 200 .

T.S. lamina showing upper, epidermis and veinlet bundle (vb) with bundle sheath $\mathrm{x} 140$
Blanford W. T. (1867). On traps and intertrappean beds of western and central India. Memo. Geol. Surv. India. 6(1):137-167.

Chitaley S. D. (1950a). fossil flower from Mohagaonkalan beds of Chindawara, cop. India. Sci. and cult. Calcutta. 15:446-447.

Chitaley S. D. (1950). Central provinces, Mohogaonkalan, Chindawara. Dist. Microflora of the Deccan Intertrappean Cherts in Paleobotany in India. J. Ind. Bot.Soc. 29:30

Chitaley S. D. (1962a). on plant fossils and fossiliferous locality Mohagaonkalan (India). Bull. Bot. Soc. Coll. Sci. Nagpur. 3:15-21.

Fahn A. (1982). Plant anatomy 3rd EDI. Pergamon press, New York, 2011.

Kapgate D.K \& Sheikh M.T. (2008): A petrified dicot leaf Salicaceophyllum mohgaonsis from Intertrappean bed of Mohagaonkalan

Kokate P.S, (2014). Deccanophyllites sheikhii

Ramteke D.D \&Kapgate D.K., (2014). A petrified fossil dicot leaf Acanthophyllum shiblii from D.I. of Shibla.

Sahni B. and Surange K. R. (1948). Central provinces. Mohagaonkalan (Chindwara dist.). in Paleobotany in India. VI. J. Ind. Bot. Soc. $26: 258$

Shallom, L. J. (1963). Contribution to the knowledge of the Deccan intertrappean flora of India. Ph.D. Thesis, Nagpur University, Nagpur.

Sheikh M. T. (1980). Three new dicotyledonous leaf impression from Deccan intertrappean beds of India. Botanique, 9:121-321

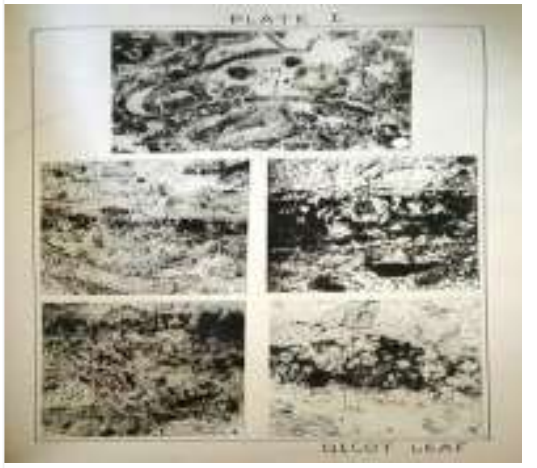

